\title{
ICT IN EDUCATION - WEB PAGES TODAY
}

\section{Jan KUBRICKÝ}

\begin{abstract}
The article deals with ICT in education, current position of these modern technologies, including their advantages and disadvantages, which may present generation of education to a large extent. More attention is paid to the service of the Internet - WWW and her near theory of connectivism, which is in educational circles have been widely discussed. Finally, this paper is a list of popular today and usable websites and applications for teaching.
\end{abstract}

Key words: Eduction, ICT, Connectivism, Web Pages

\section{ICT VE VZDĚLÁVÁNÍ - WWW STRÁNKY SOUČASNOSTI}

Resumé: Článek se zabývá problematikou ICT ve vzdělávání, současnou pozicí těchto moderních technologií, včetně jejich výhody a nevýhod, kterými mohou vzdělávání současné generace do značné míry ovlivnit. Bližší pozornost je věnována službě internetu WWW a jí blízké teorii konektivismu, která je v pedagogických kruzích dnes hojně diskutována. Závěrem př́íspěvku je uveden seznam dnes oblíbených a využitelných www stránek a aplikací pro výuku.

\section{Klíčová slova: Vzdělávání, ICT, Konektivismus, WWW stránky}

\section{1 Úvod}

V zavádění ICT do edukačních procesů bylo a je spatřováno riziko málo probádané a v mnohém nejasné aktivity (Průcha 2006, s. 310). Nicméně představit si současnou školu bez širšího využití ICT, jak ve výuce tak i mimo ni, je již prakticky nemyslitelné. Předpokládá se, že pomocí technologií se žáci učí snadněji a efektivněji, jak mj. dokazují výsledky některých rozsáhlých experimentů. Co se vlastně rozumí pod spojením ICT ve vzdělávání? Kam se tyto technologie ve vzdělávání ubírají? Dále se pokusíme některé $\mathrm{z}$ těchto otázek prodiskutovat.

\section{ICT ve vzdělávání}

Zkratka ICT je tvořena spojením dř́ve častěji použivaného IT (informační technologie) a CT (komunikační technologie). Souhrné ICT má zdůrazňovat potenciál propojení a komunikace na vysoce sofistikovaných technických řešeních, která si kladou hlavní cíl zprostředkovat člověku informace a umožnit mu komunikovat kdekoliv a kdykoliv. Obecně jsou ICT označovány jako prostředek k získávání, distribuci a manipulací s informacemi. Nebudeme se zde zabývat celým výčtem, ale zmíníme dnes ty nejaktuálnější, které značně ovlivňují oblast vzdělávání. Jedná se zejména o osobní počítače, služby počítačových sítí, internet, audiovizuální digitální techniku, telekomunikační technologie a také informační zdroje dostupné na webových stránkách, v databázích a dalších moderních datových úložištích.

Mnozí pedagogové se zabývali problematikou ICT ve vzdělávání, či pozicí konkrétních technologií ve výuce. Jak známo, je tato oblast natolik progresivní a rychle se vyvíjející, že ji nelze nikdy považovat $\mathrm{v}$ daném čase za úplnou a uzavřenou. Proto se autoři snaží o co největší univerzálnost, abstrakci a odtržení se od konkrétních technologických řešení. Zajímáme se př̀edevším o roli internetu ve vzdělávání a také využití www stránek z pohledu očekávání, která díky svým vlastnostem mohou plnit.

Se začleněním počítačů do vzdělávání se v 60 . letech minulého století prosazují směry označované počítačem podporovaná výuka a počítačem řízené učení. Počítač plní funkci didaktické techniky nebo učební pomůcky, resp. zpracovává a ukládá informace o studentovi, jeho pokrocích a výsledcích učení (Zounek 2009, s. 25). Nejznámějším prrístupem odrážejícím možnosti moderních ICT je však učení podporované počítačem. Oproti předchozím je více zaměřeno na stimulaci a podporu učení žáka při různých vzdělávacích činnostech, rozvoj jeho dovedností a kreativity. Tento směr převládá dodnes, prochází však procesem kontinuální inovace.

$\mathrm{K}$ zásadní obměně nejvíce přispěl celosvětový rozmach počítačových sítí, včele s Internetem. Došlo $\mathrm{k}$ propojení a interakci, která není ohraničena pouze na dvojici počítač a žák, nýbrž 
její hranice již v podstatě nelze stanovit. Internet a jeho služba WWW dali možnost vzniknout př́stupu učení nazvaného učení podporované webovými stránkami. Webové stránky dnes mohou plnit roli široce interaktivního a multimediálního nástroje, ale současně i jednoduchého, rychlého a dostupného místa pro sdílení informací využívaného i $\mathrm{v}$ dalších inovativních př́stupech, jako nap̌r. učení založené na zdrojích.

V současném postavení ICT ve vzdělávání tak hrají prim osobní počítače a sítové služby. Přičemž se nemusí jednat o nejkomplikovanější způsoby použití (ač bývají často chybně považovány za nejlepší možné), ale řešení, které vyřeší konkrétní potřeby a požadavky výuky. $\mathrm{K}$ problematice ICT ve vzdělávání se tak zákonitě vážou mnohé výhody, ale rovněž i některá negativa.

\subsection{Výhody ICT ve vzdělávání}

Žáci přecházejí z role pasivních př́iemců do role aktivních tvůrců vlastního poznání (konstruktivistické zásady). ICT za vhodného přispění učitele umožňuje zapojit se, pracovat $\mathrm{s}$ výukovými materiály, nečekat na sdělení, ale sami konstruovat vlastní poznatky. V této souvislosti uvedeme napríklad:

- Učitelé ve spolupráci $\mathrm{s}$ žáky využívají výhod interaktivní tabule a výukového software pro tvorbu interaktivních výukových hodin.

- Učitelé ve spolupráci $s$ žáky využívají i tvoří obsah www stránek pro výuku. (Web jako zdroj informací potřebných $\mathrm{k}$ řešení problémů. Web jako prostor prezentace informací, zakládání on-line řešitelských týmů projektových úkolů, kooperace při skupinové výuce, komunikace prostřednictvím emailu, zakládání a využívání výukových profilů na sociálních sítích atp.).

- Podpora průpravy na informální a neformální vzdělávání, ve kterém jsou dále využívány zdroje informací pro vzdělávání $\mathrm{v}$ rámci širokého spektra oborů (základy konektivistického př́istupu $\mathrm{v}$ učení). $\mathrm{Na}$ toto téma jsme publikovali $\mathrm{v}$ př́spěvku zabývajícím se problematikou vzdělávání $\mathrm{v}$ oblastech programování a tvorby www stránek (Kubrický 2010).

Z uvedených bodů zdůrazněme www stránky a službu WWW obecně. Výhody s nimi spojené jsou nutnou, nikoli ovšem postačující podmínkou zvýšení efektivity vzdělávání. Záleží především na učitelích a na žácích, kteří s nimi pracují, a na kontextu, $v$ němž jsou používány.

\subsection{Nevýhody}

Za hlavní nevýhodu je považován velmi rychlý, progresivní, a v jistých oblastech až překotný vývoj ICT. Tuto skutečnost mohou nejlépe pozorovat učitelé informační výchovy. Z vlastní praxe výuky tvorby a využití www stránek na VŠ můžeme doložit, že výukový obsah je potřeba rok co rok výrazně inovovat, držet se nových trendů a předvídat budoucí vývoj s cílem ve vytváření patřičných kompetencí budoucích učitelů.

$\mathrm{V}$ souvislosti $\mathrm{s}$ naduživáním moderních technologií ve vzdělávání je zmiňováno „odcizení“ nebo „diferenciace“ jedinců. Má se za to, že vytlačováním komunikace tváří $\mathrm{v}$ tvár̆ mohou ICT vyvolávat různé formy závislostí (např. na sociálních sítích, počítačových hrách) což může vést až $\mathrm{k}$ negativním socializačním projevům, jako je agresivita, patologické projevy chování atd. (Zounek, Šed'ová 2009, s. 25). Někteř́i učitelé si i pro tyto důvody od ICT nechávají odstup, z čehož ale mohou pramenit různé bariéry. $\mathrm{V}$ odborné terminologii se $\mathrm{v}$ této souvislosti nově setkáváme s označením digitální propast. Tímto termínem se popisují rozdíly mezi těmi, kteří mají možnost využívat ICT a využívají je pro svůj prospěch, a těmi, kteří $\mathrm{k}$ moderním technologiím prístup nemají nebo je pro svůj zdravotní handicap nemohou plně využít. Projevy digitálního rozdělení pak pozorujeme $\mathrm{v}$ (ne)konkurenceschopnosti jedince na pracovním trhu, $\mathrm{v}$ komunikaci $\mathrm{s}$ okolím, participaci jedince na výhodách, které ICT umožňují, atd.

Je jednou z prioritních úloh současné školy, aby se vyvarovala vytváření bariér, které by digitální propast mohly prohlubovat. Naopak, aby byla místem s týmem kvalifikovaných učitelů, moderním zázemím a otevřená efektivnímu využití nových technologií. Znevýhodněným jedincům musí poskytnout prostor dotáhnout se, smazat rozdíly oproti ostatním. A v kontextu $\mathrm{s}$ předchozí úvahou rozpoznávat negativní projevy, které se mohou u žáků při používání ICT objevovat. Na učitele jsou proto kladeny vysoké nároky, a ne jinak tomu musí být $\mathrm{v}$ př́padě jejich kompetencí. Zř́ejmé nároky jsou ovšem kladeny i na ICT, nebot' svou vyspělostí značně ovlivňují život ve společnosti, čímž dávají vytvořit $\mathrm{i}$ novým vzdělávacím návykům. 


\section{WWW stránky současnosti}

Služba WWW patří mezi tři nejpouživanější služby internetu. Z původního prostředí pro sdílení a prohlížení textových dokumentů se stala centrem ohromného množství hypertextových a hypermediálních objektů, a synonymem pro snadné, rychlé a levné sdílení informací. Současná strategie (verze) služby WWW označovaná jako Web 3.0 je oproti minulosti více zaměřena na interakci uživatelů, sdílení vlastních informací a nově použití mobilních technologií.

Stručně popíšeme ono označení Web 3.0. Jak název napovídá, jedná se o třetí fázi vývoje webu, z hlediska technologické, uživatelské a obsahové přístupnosti. První fáze byla založena na síti hypertextových dokumentů, o jejichž tvorbu a provázanost se zasloužila především komunita odborníků. S rychlým vývojem webových nástrojů a tím souvisejících aplikací, získávají svůj podíl na tvorbě webu i běžní uživatelé. Ze statických konzumentů informací se stávají aktivními tvưrci. Druhá fáze nese označení Web 2.0 a je charakteristická hesly „sdílení“ a „komunikace“. Web 2.0 pokračuje vlastně dodnes, nicméně mnozí jej $\mathrm{v}$ dalším progresu a rozširirení technologií již označují za Web 3.0. Z hlediska orientace na vzdělávání zmíníme tyto možnosti využití:

- sdílené aplikace - např. on-line tvorba textů podporující okamžitou spolupráci více uživatelů (učitelů $i$ žáků),

- př́stup na web přes aplikace pro různá zařízení - využití webu jak na osobním počítači, tak např. $v$ mobilních zařízeních či televizorech,

- větší interakce na softwarové úrovni účastnící vzdělávacího procesu být nejen tvůrci obsahu, ale rovněž tvưrci programů (např. formuláŕe, ankety atp.),

- dotazování $\mathrm{v}$ přirozeném jazyce efektivnější vyhledávání materiálů a budování široké informační základny konkrétních témat pro výuku,

- širší využití videa - podpora názornější a rozmanitější výuky, podpora nových vzdělávacích potřeb žáků vyplývajících s jejich zájmů a trávení volného času.

Stěžejní charakteristiky webu, o které se budeme dále opírat, jsou dnes již téměř neohraničené možnosti obsahové prezentace, dostupnost a př́stupnost běžnému uživateli, multimedialita, interaktivita, komunikace a sdílení. Následkem těchto vlastností se znatelně mění práce uživatelů, a není proto překvapením, že se mění také proces učení a celý systém vzdělávání. Tyto změny se snaží reflektovat nový vzdělávací model založený na principu sítě, který spojuje učitele a studující (umožňuje spolupráci a kontakt) a je nazýván konektivismus (Šimonová 2010). V moderním pojetí se konektivistické učení se stává nutně také cílem vzdělávání, kterého je potřeba vzhledem $\mathrm{k}$ současnému př́stupu a výměně informací dosáhnout; tj. v prvé řadě přijmout vzdělávací perspektivy ICT a využít je pro učení a další rozvoj.

\section{Konektivismus}

Konektivismus vyjadřuje učení jako proces, jehož hlavní podstata je zaměřena na propojování různých informačních zdrojů, ale i propojování lidí, kteří sdílejí znalosti a komunikují prostřednictvím sítí v reálném čase. M. Šimonová (2010, s. 80) míní, že „tímto se vytvářejí mnohem širší možnosti pro získávání informací a znalostí než při individuálním využívání moderních technologií“. Pro současnou generaci žáků a studentů toto představuje hlavní zdroj motivace $\mathrm{k}$ učení a $\mathrm{k}$ jeho efektivnímu průběhu, což prrirozeně vede $\mathrm{k}$ nutnosti realizace změn statického př́stupu školního vzdělávání. Do popředí se proto dostávají moderní formy výuky.

Učení založené na principech konektivismu je důležitým ukazatelem, jehož hlavní body $\mathrm{v}$ kontextu využivání www stránek pro vzdělávání jsou tyto (Brdička 2008 a Zounek 2009):

- využití www stránek jako centra propojení různých informačních zdrojů,

- navazování na různorodé zkušenosti žáků s využitím www stránek,

- navozování a udržování spojení, prohlubování spolupráce žáků a sdílení znalostí prostřednictvím www stránek,

- udržování přesnosti a aktuálnosti informací, včetně jejich distribuce za použití www stránek,

- využití www stránek jako neživého nástroje učení (formování struktury sítě a cesty k vyhledávání informací).

\section{Př́íklady WWW pro výuku}

Následující část je věnována stručnému přehledu www stránek a webových aplikací, které jsou dnes pro potřeby výuky nejčastěji využívány. 


\section{Wiki}

Stránky označované jako „Wiki“ jsou určeny pro sdílení širokého spektra informací, formou textu, až po vyspělé multimediální objekty. Jejich obsah bývá zaměřen na konkrétní pojmy, události, osoby, technologie atd., které jsou provázány hypertextovými odkazy a tvořící většinou obrovské informační databáze (např. Wikipedia). Učitelé jich využivají pro potřeby prezentace informací, jako zdroje informací pro žáky při řešení úloh, i jako kreativní prostředí umožňující žákům spoluvytváření obsahu Wiki.

\section{Blog}

Webové blogy si dnes zakládá celá řada uživatelů pro účely jednoduchých deníků, až po zpravodajství vědeckých závěrů atp. Tvořit obsah může striktně jedna osoba nebo i celá komunita uživatelů. Obsah dnešních blogů může zahrnovat téměř veškeré multimediální objekty a vzhledem ke snadné obsluze se tato aplikace stává jednou z nejrychleji se rozšiřujících na internetu a rychle proniká i do oblasti vzdělávání. $Z$ pedagogického hlediska vnímáme jako pozitivní skutečnost, že učitelé si sami zakládají blogy, prezentují na nich výukové materiály, spolupracují na jejich obsahu spolu s žáky.

\section{Sociální sítě}

Dnes nejdiskutovanější. Žáci tráví na sociálních sítích stále více času, přičemž je potřeba této skutečnosti využít ve prospěch jejich vzdělávání. Ovšem objevují se i alarmující př́pady diferenciace, zneužití a kyberšikany.

\section{Google}

Množství a širre nástrojů společnosti Google nabízí oblasti vzdělávání velké pole zhodnocení. Lze využívat různých možností vyhledávače, překladače, kalendáře, mapy, satelitních snímků na Zemi, databáze vědeckých prací, nebo nového nástroje Google Apps pro vzdělávání. Žáci mohou $\mathrm{v}$ jednom čase tvořit a upravovat textové dokumenty, spolupracovat na tvorbě on-line prezentací, komunikovat mezi sebou a vytvářet řešitelské skupiny. Nástroje Google podporují různé styly učení, umožňují aktivizovat žáky interaktivními prvky, zahrnují metody podporující samostatnou práci žáků, metody rozvíjející tvořivé dovednosti.

\section{Závěr}

Problematika ICT se dotýká oblasti vzdělávání ve stále větší míře. A nelze opomíjet skutečnost, že nejvíce zainteresovanou oblastí je služba WWW, která dříve či později pohltí všechny známé způsoby komunikace a tedy i kanály distribuce informací. Je nutné si pokládat otázky, jak se tomuto trendu přizpůsobit, jak reagovat a vylepšovat nejen obsah vzdělávání, ale především jeho formu. S rostoucími možnostmi a výbornými nástroji lze nacházet cesty, které otvírají dveře vzdělávání v 21. století, přičemž ale nelze tyto změny zavádět násilně, na úkor potlačení osobnosti učitele a žáka, a jejich přirozeného sociálního kontaktu.

\section{Literatura}

[1] ZOUNEK, Jiří, 2009. E-learning - jedna z podob učení $v$ moderni společnosti. Brno: Masarykova Univerzita. ISBN 978-80-210-51232.

[2] ZOUNEK, Jiří a ŠEĎOVÁ, Klára, 2009. Učitelé a technologie. Brno: Paido. ISBN 97880-7315-187-4.

[3] ŠIMONOVÁ, Ivana aj., 2010. Styly učeni v aplikacích eLearningu. Hradec Králové: Miloš Vognar. ISBN 978-80-84771-44-1.

[4] BRDIČKA, Bořivoj, 2008. Konektivismus teorie vzdělávání $\mathrm{v}$ prostředí sociálních sítí [online]. Učitelský spomocník. [cit. 2011-04-05]. Dostupné http://www.spomocnik.cz/pub/Konektivismus_B B08.pdf

[5] KUBRICKÝ, Jan, 2010. Aktuální trendy vzdělávání $\mathrm{v}$ oblasti programování a tvorby webových aplikací. In: Modernizace vysokoškolské výuky technických předmětů. Sborník příspěvků a anotací mezinárodní vědecké konference [CD-ROM]. Hradec Králové: GAUDEAMUS. ISBN 978-80-7435-014-6.

[6] PRŮCHA, Jan, 2006. Pedagogická věda a nové výzvy edukační praxe. Pedagogika, roč. 56, č. 4, s. 307-315. ISSN 0031-3815.

\section{Mgr. Jan Kubrický}

Katedra technické a informační výchovy

Pedagogická fakulta UP

Žižkovo nám. č. 5

77140 Olomouc, $\check{C} R$

Tel: +420 585635806

E-mail: jan.kubricky@upol.cz

Www pracoviště: http://kteiv.upol.cz/ 